rat, pt. Wychowanie dziecka $w$ XIX stuleciu $w$ świetle praktycznych porad Lucyny Ćwierczakiewiczowej, zaprezentowały wspólnie mgr Grażyna Czerniak i mgr Justyna Zyśk z Uniwersytetu Warmińsko-Mazurskiego w Olsztynie. Ostatni referat sesji wygłosiła mgr Daria Domarańczyk z Uniwersytetu Łódzkiego, omawiając temat Psychologia dziecka na łamach prasy Królestwa Polskiego i Galicji przełomu XIX i XX wieku.

Po wystapieniach prelegentów był czas na kolejną dyskusję na temat zaprezentowanych tekstów. Głos zabrali: dr Marzena Iwańska, dr Joanna Sosnowska, dr Antoni Maziarz, Maria KorybutMarciniak, mgr Piotr Bojarski, mgr Marta Kłak Ambrożkiewicz, prof. Kita oraz prof. Marta Sikorska-Kowalska.

Zakończeniu obrad sesji towarzyszyło podsumowanie wygłoszone przez organizatorów - prof. nadzw. dr. hab. Jarosława Kitę oraz dr Marię Korybut-Marciniak. Uczestnicy usłyszeli także podziękowania oraz zostali zaproszeni na kolejna, czwarta sesję naukowa wspólnie organizowana przez zaprzyjaźnione ośrodki badawcze. Po spożytym obiedzie prelegenci $z$ różnych miast $w$ Polsce wrócili do domów.

SYLWANA BORSZYŃSKA UNIWERSYTET ŁÓDZKI*

http://dx.doi.org/10.18778/1644-857X.14.02.18

\title{
Widzieć obrazem. Reżyser Hanna Etemadi w Instytucie Historii Uniwersytetu Lódzkiego, 21 października 2015 r.
}

Pani Hanna Zofia Etemadi, od lat zwiazana $z$ Warszawa, zawsze podkreśla, że najlepiej czuje się w Lublinie, swym mieście rodzinnym, gdzie przyszła na świat. Jej ojciec, Leon Pokrywka, wywodzący się z Zamojszczyzny, ukończył studia prawnicze na Katolickim Uniwersytecie Lubelskim i ekonomię polityczna na Uniwersytecie Jana Kazimierza we Lwowie. Edukację wojskową otrzymał w WoXIX wieku.

* Wydział Filozoficzno-Historyczny, Instytut Historii, Katedra Historii Polski 
łyńskiej Szkole Podchorażych Rezerwy Artyleryjskiej we Włodzimierzu Wołyńskim. Wykorzystał potem tę wiedzę $\mathrm{w}$ partyzantce lubelskiej związanej $z$ ruchem chłopskim. Matka, Zofia Krzyżanowska, córka kolejarza $z$ Lublina, wychowanka renomowanej szkoły urszulanek, studiowała prawo na KUL-u i tam poznała swego przyszłego męża. Przed wojną zdażyła już być sędzią. Była kobieta niezwykle urodziwa, co uwieczniły m.in. fotografie Edwarda Hartwiga, i miała piękna, rzadko spotykana, wagnerowska barwę głosu - kontralt, ale jej kariera nie rozwinęła się w tym kierunku. Rodzice żyli na wysokiej stopie w domu przy alei Piłsudskiego, skąd po zwycięstwie Niemców zostali przekwaterowani na ul. Dolna Panny Marii. Matka pani Hanny otwarła sklep z kapeluszami na Podzamczu, na ul. Świętoduskiej, i dzięki temu utrzymywała rodzinę podczas okupacji, dając jednocześnie schronienie trzyosobowej rodzinie żydowskiej o zmienionej tożsamości: Jerzemu, Julii i Bogdanowi. Julia, niepodobna do Żydówki, pomagała w sklepie jako czeladniczka. Dom był komórka konspiracji, ale, jak powiada pani Hanka, mieszkało się bezpiecznie, ponieważ w kamienicy znajdowała się elegancka restauracja dla Niemców. Dziewczynka wychodziła na spacery do Ogrodu Saskiego w towarzystwie młodzieńca o imieniu Zbyszek. Nie wie, czy był cichociemnym czy łącznikiem. Nie mówiło się o tym. Mecenas Pokrywka, związany z partyzantka leśna, dla niepoznaki hodował tytoń w Lublinie nad Bystrzyca, przy torach wyścigowych. Ta informacja ma znaczenie, gdy niedługo potem, jako urzędnik Ministerstwa Rolnictwa, odbudowywał przez UNRRA stadninę koni rasowych. Matka, $z$ pania Ireną Skarżyńska, kapitanem AK, ratowała jak mogła dzieci z Zamojszczyzny przeznaczone na zagładę, zamarzajace $\mathrm{w}$ bydlęcych wagonach zima roku 1942/1943. Pracowała także dla Delegatury Rządu na Kraj, wspomagajac obozy jenieckie i wysyłając paczki m.in. do Buchenwaldu, skad odwrotna pocztą otrzymywała wzruszające dowody wdzięczności w postaci puderniczki ze słomy czy szachów $z$ chleba, a przede wszystkim miniatur portretowych, robionych na niemieckich kartkach pocztowych na podstawie zdjęć dołaczanych do paczek. Natychmiast po wejściu Rosjan w lipcu 1944 r. matka pani Hanki dostała się w ręce NKWD i była przesłuchiwana na Zamku Lubelskim. To dojmujące doświadczenie zmieniło kompletnie jej charakter. Do niedawna odważna kobieta, od tej pory żyła w strachu. Ojca wtedy nie było. Jako działacz chłopski, bezpartyjny prawnik, włączył się w przygotowania reformy rolnej. 


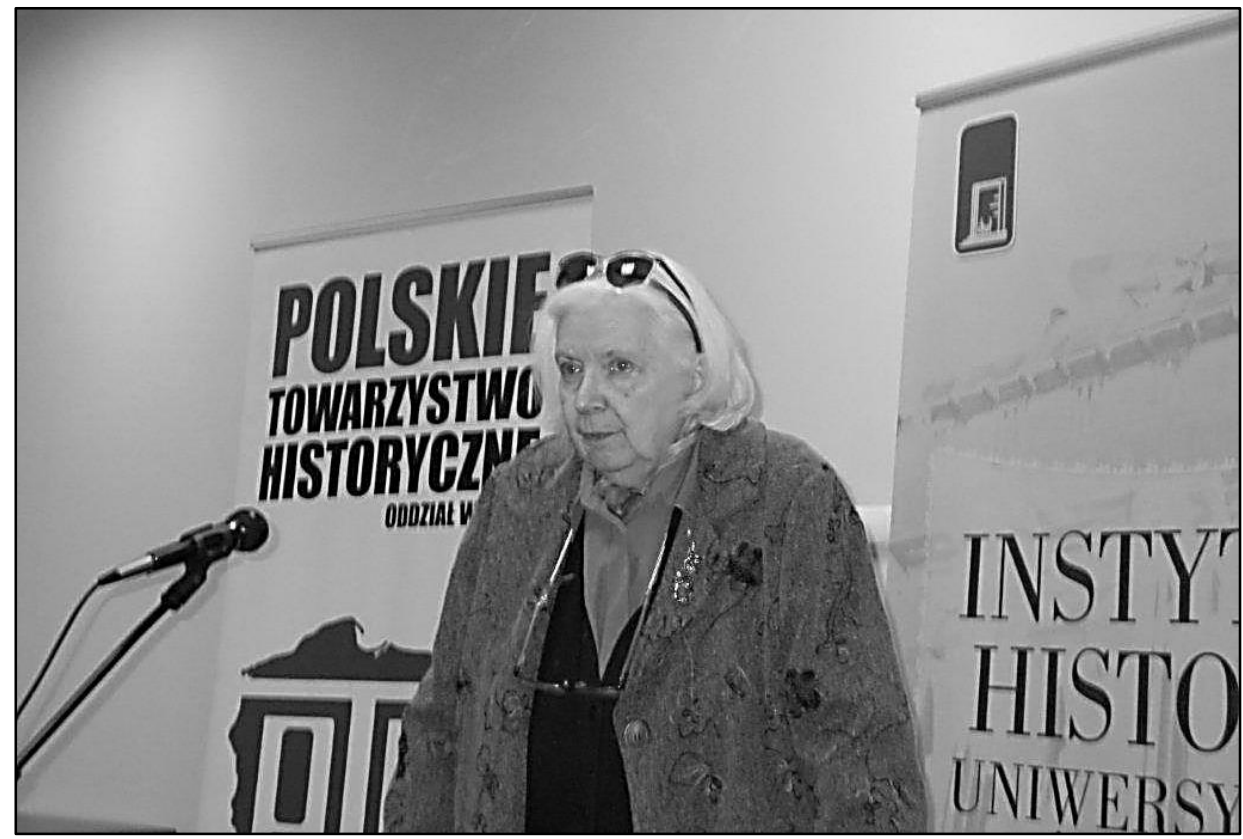

Hanna Etemadi w czasie wykładu w Łodzi, fot. M. Dąbrowska

W 1945 r., kiedy Łódź stała się tymczasową stolicą Polski, Hanna $z$ rodzina pojawiła się tutaj. W następnym roku urodził się jej brat Andrzej Janusz. Ojciec pracował w budynku rzadowym na rogu ul. Legionów i Gdańskiej, a cała rodzina zajęła parterowe mieszkanie $\mathrm{w}$ poniemieckim okazałym gmachu $z$ lat trzydziestych, mieszczącym się przy skrzyżowaniu ulic Zielonej i Gdańskiej. To był świat małej Hani, która przez cztery lata uczęszczała do szkoły panny Wesołkówny przy ul. Piotrkowskiej 120. Kariera ojca trwała krótko. Związał się ze stronnictwem Stanisława Mikołajczyka, po którego wyjeździe $z$ kraju musiał uciekać i schronił się na Zamojszczyźnie, a matka była nadal modystka, prowadząc elegancki sklep z kapeluszami i galanterią damska, mieszczący się na początku ul. Piotrkowskiej, tuż przy placu Wolności. W 1949 r. rodzina przeniosła się do Warszawy i o tym okresie do czasu 1956 r. pani Hanna mówi najmniej, bo wtedy w ogóle niewiele się mówiło. Ojcu odmówiono praktyki prawniczej, pracował w Centrali Mięsnej, a matka dostała pozwolenie na radcostwo w Szkole Głównej Gospodarstwa Wiejskiego.

Pani Hanna skończyła żeńskie liceum im. Słowackiego i jej zainteresowania jako młodej dziewczyny zmierzały w kierunku śpie- 
wu operowego i teatru. Matka odwiodła córkę od kariery śpiewaczej i skłoniła panienkę $z$ dobrego domu do gry na fortepianie. Jeszcze w liceum Hania zaczęła pisać wiersze, dobrze oceniane przez samego Władysława Broniewskiego. Nie bez trudności bohaterka tej opowieści zdała egzaminy wstępne do Szkoły Teatralnej, ale mimo wysokiej oceny Aleksandra Zelwerowicza i Zofii Małynicz została zdyskwalifikowana przez lekarza $z$ powodu przebytej gruźlicy. Na Wydziale Polonistycznym dostała się na teatrologię bez egzaminu, już jako uznany talent literacki, który dalej przejawiał się w felietonach teatralnych pisanych dla „Przegladu Kulturalnego” i „Kultury”. Na teatrologii studiowała m.in. u prof. Jana Kota, który zalecał się do pięknej dziewczyny. Zaprzyjaźniła się z Aliną Lorentzówną, później Kowalczykową, oraz Ewą Kreczmar. Pracę magisterska na temat Zygmunta Kisielewskiego napisała pod kierunkiem prof. Jana Zygmunta Jakubowskiego. Nie rezygnowała z głównej pasji. Jako wolny słuchacz uczyła się aktorstwa u Mariana Wyrzykowskiego oraz reżyserii u Bohdana Korzeniowskiego. Idąc tropem zainteresowań polonistycznych, rozpoczęła przewód doktorski pod kierunkiem prof. Stefanii Skwarczyńskiej z Uniwersytetu Łódzkiego. Dzięki tej badaczce poznała wnuczkę Heleny Modrzejewskiej, Marylę M. Pattison, malarkę, której pomagała $\mathrm{w}$ przekazaniu pamiątek po wielkiej aktorce do Teatru Wielkiego w Warszawie, w którym są eksponowane do dziś.

Doktorat przegrał $z$ telewizja, w której pani Hanna znalazła swe miejsce w $1963 \mathrm{r}$. Była jedna $z$ nielicznych osób pracujacych w tej instytucji, która miała studia wyższe, co, jak zaznacza, było tępione na wszystkie sposoby przez kierownictwo $z$ awansu. Pani Etemadi mówi o sobie, że „widzi obraz”. Współpracowała przy spektaklach teatralnych $z$ Jerzym Gruza i współtworzyła $z$ Aliną Konstanciakową pierwszy w telewizji magazyn dla kobiet "Nie tylko dla pań". Jednocześnie zaczęła filmować pokazy mody i te felietony telewizyjne, wysoko oceniane przez Jadwigę Grabowską, kierująca „Moda polska”, były wysyłane za granicę. Pani Hanna podkreśla, że była samoukiem. Nikt jej nie uczył filmowania. Dzięki jej wyobraźni reklama w telewizji zaczęła istnieć, o czym się nie pamięta. Pierwsze spoty reklamowe były jej autorstwa. Tworzyła też pierwsze programy żywieniowe. Dla niej zbudowano pierwszą kuchnię telewizyjną. Prowadziła również audycje: „Czas rodzin” oraz „Dom i my”. Współtworzyła $z$ Jerzym Sosnowskim magazyn „Na półkach księgarskich”. Wszystkie formy telewizyjne, studyjne i filmowe były w polu jej zainteresowań, ale coraz bardziej kierowała się w stronę 
filmu. W latach siedemdziesiatych nakręciła około 500 sześciominutowych miniatur literackich „od A do Z”. To prawdziwe perły montażu, poświęcone literaturze polskiej od początku istnienia aż do pisarzy zakazanych w PRL, takich jak Jerzy Giedroyć, Aleksander Wat czy Włodzimierz Odojewski. Te ostatnie filmy nie były emitowane. Pierwszy film biograficzny Hanny Etemadi dotyczył Marka Hłaski. Jednocześnie, za namowa pisarza, Zbigniewa Bieńkowskiego, zaczęła kręcić filmy o postaciach zakazanych, przede wszystkim o poetach z kręgu „Sztuki i Narodu”: Tadeuszu Gajcym, Leonie Stroińskim i Andrzeju Trzebińskim. Na realizację obrazu o Wacławie Trzebińskim już nie dostała pieniędzy. Zainteresowania artystyczne szły w parze $z$ innymi pasjami. Zwiazana $z$ PCK, pani Etemadi prowadziła $\mathrm{w}$ telewizji program o krwiodawstwie i $z$ tego powodu zaangażowała się w działalność na cmentarzysku w Palmirach, które zaczęto porządkować dopiero w latach sześćdziesiątych. Ten dramat znalazł również odzwierciedlenie w jej twórczości.

W 1964 r. poślubiła Habiba Etemadiego, wywodzacego się z rodziny królewskiej, jednego $z$ dwóch pierwszych Afgańczyków, którzy rozpoczęli studia w Polsce. Po ukończeniu łódzkiego Studium Języka Polskiego dla Cudzoziemców Habib studiował inżynierię gospodarki wodnej na Politechnice Warszawskiej i swa pracę zawodowa poświęcił regulacji Wisły. Był wybitnym racjonalizatorem i wiele jego osiagnięć zostało uhonorowanych wysokimi odznaczeniami państwowymi. Habib przesiąkną tradycja i kultura polska i z Hanna bywał częstym gościem w Ambasadzie Afganistanu, gdzie przez wiele lat jego brat stryjeczny był ambasadorem. Bywanie skończyło się, gdy Afganistan, w wyniku krwawego przewrotu, został republika w 1973 r., a rodzina męża straciła wielu krewnych. Pani Hanka podkreśla, że była pierwszą Polka, która wyszła za Afgana, po tym, jak ów zapewnił MSZ, że nie popełni wielożeństwa, tym więcej że w jego środowisku obyczaj ten wcale nie istniał. Ślub odbył się w USC na Starym Mieście, a wesele w „Bristolu”. Młoda para zamieszkała na Ścianie Wschodniej. W 1965 r. urodził się ich syn Piotr. W latach dziewięćdziesiątych rodzina kupiła dom w Piasecznie, przy ul Trele. Habib zmarł w 1997 r. i jako mahometanin został pochowany na warszawskich Powazkach.

Pani Hanna ciagle tęskni do Lublina, „miasta na siedmiu wzgórzach", jak Rzym. Powiada, że talent literacki odziedziczyła po matce, natomiast tematyka jej filmów dokumentalnych odzwierciedla losy rodzinne obojga rodziców. W ostatnich latach pani Etemadi tworzy filmy historyczne, a to o Delegacie Rząu na Kraj, 
prof. Janie Piekałkiewiczu, a to o dzieciach Zamojszczyzny, w których porusza także watek dziecięcego obozu w Łodzi przy ul. Przemysłowej, teraz zaś zbiera materiały do filmu o ostatnim wojewodzie lubelskim, Jerzym Albinie de Tramecourt, po którym ślad zaginą, podobnie jak po prezydencie Warszawy Stefanie Starzyńskim. Nie wiadomo, co się $z$ nimi stało.

Hanna Zofia Etemadi przyjechała do Instytutu Historii Uniwersytetu Łódzkiego $z$ filmem o akcji AB dotyczacym eksterminacji inteligencji polskiej przez Niemców w Generalnym Gubernatorstwie w 1940 r. Projekcja i wykład w dniu 21 października 2015 r. miały duża publikę, a pytania świadczyły o żywym zainteresowaniu zebranych. Podczas pobytu w Łodzi pani Etemadi odwiedziła miejsca dzieciństwa oraz pierwsza siedzibę Szkoły Teatralnej przy ul. Gdańskiej (obecnie Akademia Muzyczna). Wspomniała o licznych przyjazdach do ośrodka łódzkiego Telewizji Polskiej, gdzie pracowała nad filmami poświęconymi projektom modowym Jerzego Antkowiaka czy Anny Skórskiej, kierującej „Telimena”.

Mimo tylu sukcesów Hanna Etemadi żałuje, że nie podjęła śpiewu operowego i żałuje tańca. Tańca indywidualnego, który improwizowała w stylu Isadory Duncan. Chciałaby nakręcić jeszcze kilka filmów, póki żyją postaci tak barwne, jak Barbara Kraftówna. Tytuł tego dokumentu brzmiałby „Kabaret starszej pani”. „Tyle pomysłów się zmarnowało. Powinno być inaczej" - powiada $z$ żalem, po czym kwituje to jednym słowem: kismet, oznaczającym przeznaczenie.

Historyczna pasja pani Hanny przejawia się w wyłuskiwaniu z przeszłości bohaterów zapomnianych. Mimo swego zmęczenia robi o nich filmy, dlatego że, jak podkreśla, „nasza tożsamość narodowa ulega degradacji. Od takiego kalectwa chciałabym uchronić młodzież, przynajmniej niektórych" - powiada. Premiera filmu poświęconego najmłodszej legionistce Piłsudskiego, przedwojennej senator $z$ listy lubelskiej, Helenie Jaroszewiczowej, zamordowanej w Palmirach w 1940 r., przewidziana jest na 10 listopada 2015 na Zamku Lubelskim.

Rozmowa spisana 20 października, autoryzowana 3 listopada 2015 r.

MAEGORZATA DĄBROWSKA UNIWERSYTET ŁÓDZKI*

\footnotetext{
* Wydział Filozoficzno-Historyczny, Instytut Historii, Katedra Historii Średniowiecznej.
} 